Journal of Southeast Asian

\title{
Do I Look Up or Do I Look Down? Reflections of a Hmong American English Learner and Educator
}

Kay Vang

California State University Stanislaus, kvteach@yahoo.com

Follow this and additional works at: https://docs.lib.purdue.edu/jsaaea

Part of the Education Commons

\section{Recommended Citation}

Vang, Kay (2009) "Do I Look Up or Do I Look Down? Reflections of a Hmong American English Learner and Educator," Journal of Southeast Asian American Education and Advancement. Vol. 4 : Iss. 1, Article 5. DOI: $10.7771 / 2153-8999.1096$

Available at: https://docs.lib.purdue.edu/jsaaea/vol4/iss1/5

This document has been made available through Purdue e-Pubs, a service of the Purdue University Libraries. Please contact epubs@purdue.edu for additional information.

This is an Open Access journal. This means that it uses a funding model that does not charge readers or their institutions for access. Readers may freely read, download, copy, distribute, print, search, or link to the full texts of articles. This journal is covered under the CC BY-NC-ND license. 


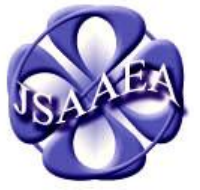

Volume 4 (2009)

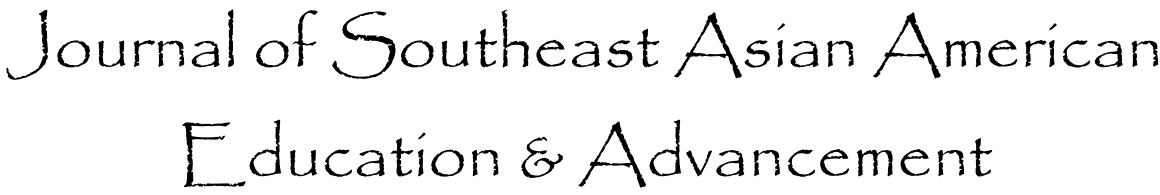

WWW.JSAAEA.org
A peer-reviewed

scholarly journal

published by the

National Association

for the Education \&

Advancement of

Cambodian, Laotian,

and Vietnamese

Americans (NAFEA)

\title{
Do I Look Up or Do I Look Down? Reflections of a Hmong American English Learner and Educator
}

\author{
Kay Vang \\ California State University Stanislaus
}

\begin{abstract}
Drawing from my own schooling experiences as an English learner, I share my views and beliefs in relation to the deficit model, assimilation model, and caring model. I especially focus on experiences of English learners, as they are the fastest growing subgroup in the nation. I further share and discuss challenges that some EL students may experience at school along with some teacher perceptions and attitudes.
\end{abstract}

The English learner (EL) student population has increased tremendously over the years. Overwhelmingly, these students are reared in homes in which English is not the primary language spoken. Moreover, a disproportionately high percentage of these students are raised in poverty and attend poor schools (Walqui, 2006). ELs start school significantly behind their English speaking peers and require extra attention. For these students, learning English along with the American culture can be especially challenging. As a Hmong-American student and educator, I can relate to the school experiences of many English learner students having gone through the public school system myself. Today, I use my experiences to better myself as an educator and to help me understand these EL students. Moreover, I share my experiences through three diverse and important conceptual lenses related to education which not only help shed light on my own experiences as an EL, but that also provides a better view of how our education system, and more importantly, individual teachers can improve learning experiences for this growing population of students. These include the deficit model (Stein, 2004; Nieto, 2005), assimilationist model (Stevens, Wood, \& Sheehan, 2004), and caring theory (Noddings, 1992).

As educators, we cannot give up on our students. The relationships we build with our students can have positive effects on them and their future. For me, I had a teacher who believed in me and helped me succeed in school. My parents were also very supportive and loving. They valued the importance of education and instilled that belief in me from a very young age. I have always enjoyed school and knew early on that I wanted to be a teacher when I grew up. Even though I was held back in kindergarten due to my lack of English skills, I eventually learned the language over time and am still learning to this day. My school experiences have further inspired me to be an educator and work passionately with students, especially EL students.

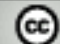

SORERIGHISRESERVEDReaders are free to copy, display, and distribute this article, as long as the work is attributed to the author(s) and the Journal of Southeast Asian American Education \& Advancement, it is distributed for noncommercial purposes only, and no alteration or transformation is made in the work. More details of this Creative Commons license are available at http://creativecommons.org/licenses/by-nc-nd/3.0/. All other uses must be approved by the author(s) or JSAAEA. 
Under No Child Left Behind (NCLB), public schools must make Adequate Yearly Progress (AYP) in both English-Language Arts (ELA) and in Mathematics. Schools that do not make AYP in the same content area for any numerically significant subgroup for each of the two consecutive years will be identified for Program Improvement (PI). One of those numerically significant subgroups struggling to make AYP in California's public schools is English learners. Without these state mandates, I believe the needs of ELs would still be overlooked. NCLB has brought the attention of ELs and other subgroups to the forefront in public education. Until recently, very little attention was paid to teaching EL students. Currently, English Language Arts (ELA) programs on the state-adopted list must have an EL component. Although California schools are not required by law to provide a stand-alone English Language Development (ELD) curricular program for their EL students, many schools are now doing so.

Currently, I work for Patterson Joint Unified School District (PJUSD) in Stanislaus County in California's central valley. I taught second, third, and fifth grade my first nine years in the district. Afterwards, I was promoted to English Learner Instructional Coach for the following two years and am currently an assistant principal. PJUSD's EL student population is approximately 34 percent, with 21 different languages being spoken and Spanish being the predominant primary language. PJUSD is a good representation of the overall demographic of the region as well as many parts of the state and nation. As a Program Improvement District, PJUSD is committed to providing professional development for the purpose of building academic language and increasing support for EL students. These trainings provide teachers with strategies to work with EL students. These strategies not only benefit EL students but all students as well. Teaching strategies such as Specially Designed Academic Instruction in English (SDAIE) and Sheltered Instruction have been around for years. These strategies prove to be extremely effective with English learners when implemented correctly (Teaching Diverse Learners, 2006). Teachers who implement these strategies in their classes know how to modify instruction delivery so that ELs can have access to content standards. PJUSD also utilizes other research-based instructional strategies such as A+ RISE (Arroyo, 2007) to help ELs acquire academic English while mastering content. As an assistant principal who does staff development trainings, I have a huge impact as to how I can assist teachers in working effectively with students, especially EL students.

From my schooling experiences, my teachers seemed to lack these strategies to help me. I often wonder how much training and support my teachers received. As early as kindergarten, I remember being pulled to the back table by a paraprofessional, who worked with a small group of students. Unfortunately, I remember just sitting there and not being actively engaged in any instructional activity. Moreover, the paraprofessional seemed to care less that any of us were not participating since she did most of the talking at us instead of talking with us. I used to dread going to the back table because it was boring. When I was a teacher, I tried to provide my EL students with ample opportunities to speak. This collaborative interaction is central to the language acquisition process, both for oral and written language development. Therefore, I strongly encourage teachers to allow students to speak about what they are learning. Students need to be active learners rather than passive learners. Today, teachers are better trained to work with EL students; however, they are still in need of on-going training. As a staff developer, I can provide teachers with the necessary resources and have a bigger impact on student learning.

Research shows that EL students are more likely to be taught by teachers without appropriate teaching credentials and with little classroom experience. A recent study of 4,800 teachers of EL students in California responding to a survey about the challenges they faced in 
teaching ELs found large percentages of these teachers expressing concern that they were not prepared to teach these students (Gandara, Rumberger, Maxwell-Jolly, \& Callahan, 2003). Sadly, I hear the same concerns from some teachers within the district, and previous EL shadowing activities further validated their concerns. Through this activity, I noticed that EL students were not given enough opportunities to engage in oral language development. Additionally, I found there was little teacher-student interaction. Clearly, students were not as involved in "doing" as in simply watching. As much as we know about what works with EL students, we are still lacking in this area.

Some people might argue that EL students' failure to achieve could be explained by their so-called deficits. Stein (2004) and Nieto (2005) explain that deficit theories believe students of racial minority and economically poor backgrounds are genetically or culturally inferior when it comes to learning. For example, buzzwords such as "low performing," "at risk," and "disadvantaged" are often used to describe ELs who do not achieve proficient or better on standards-based assessments. Using these terms to describe these students clearly identifies their lack of English skills as a deficit. Interestingly, the argument commonly made is that students must be proficient in English to have access in the American society. In contrast, other industrialized nations tend to teach their students to be proficient in their native language as well as in English. For instance, during my visit to Thailand, I was amazed that my cousins not only spoke Hmong and Thai, but they also spoke English. When my cousins from France visited, they were also trilingual.

In America, we seem to stress the importance of learning English only. From my point of view, being bilingual is an advantage rather than a "deficit." Recently in the United States, there has been "the recognition by policymakers and educators that the United States has a critical need for residents who are proficient in more than one language" (Howard \& Christian, 2002, p. 1). The debate over bilingual education has long been a hot-bed of emotions and political action. California, with its substantial numbers of English learners, has often been at the center of controversy with its history of court cases, bilingual education advocacy, and immigration history. Culminating in 1996 with Proposition 227, a backlash against bilingual education and immigrant rights led to the near abolition of bilingual education in California and set a precedent for other states to follow. In the end, Proposition 227 was approved by 61 percent of California voters, due to the fact that 65 percent of Californians agreed with the statement that "If you live in America, you should speak English" (Olsen, 2009). Not surprisingly, I have actually heard this statement from teachers too. There is an underlying opinion that immigrants are outsiders who come into this country with diverse cultures, languages, and perspectives that have potential to destabilize cultural norms as well as the economical and ideological status quo. The assimilationist model believes that a common, national civic culture is a critical to the survival of the nation (Stevens, Wood, \& Sheehan, 2004).

Payne (1996) believes that schools operate from the perspective of middle-class norms. This belief is not a new concept as it has been addressed in other books such as Justice, Ideology, Education (Stevens et al., 2004) in which the authors point out that organizations, including schools, have rules that were established by powerful white males and operate within that cultural paradigm. Hence, almost all the experiences discussed in American classrooms are approached from the standpoint of White perspectives and history. Multicultural education too has been tremendously controversial since its beginnings as some people view it as a threat to a common U.S. culture. However, the lack of multicultural education hurts students as they remain 
essentially ignorant of the contributions of a major portion of the world's people (Stevens et al., 2004).

Payne (1996) argues that educational tests are biased and favor middle class students. She states every language in the world has these five registers: frozen, formal, consultative, casual, and intimate. However, EL students generally do not have access to the formal register at home. Overwhelmingly, they are reared in homes in which English is not the primary language spoken. Although ELs quickly acquire basic interpersonal communication skills, it takes about 5-7 years for most ELs to gain sufficient mastery of academic English (Cummins, 1999). Most educators assume that if students can speak English in social settings then they have a command of the English language. Therefore, Payne argues that the ability to use the formal register is a hidden rule of the middle class, which is also supported by Basil Bernstein (Sadovnik, 2001) who states that "schools require an elaborated code for success means that working class children are disadvantaged by the dominant code of schooling" (p. 2-3).

Upon starting school in the eighties, I only spoke my primary language, Hmong. During this time, there was a huge influx of Southeast Asian students as a result of the Vietnam War. Schools were unprepared to teach these new EL students who had never been schooled before. Looking back on my own educational experience as an EL student, I wonder how I have made it thus far in my educational endeavor. For example, some schools lacked well-qualified paraprofessionals and teachers who could adequately teach EL students like myself. During my elementary years, a few of the schools had Hmong-speaking paraprofessionals. However, I recall that most of them either spoke broken English or had thick accents, which did not help me learn English. Besides speaking my native language, these paraprofessionals lacked the appropriate trainings to work effectively with Hmong-speaking students. Furthermore, the teachers I had seemed lost as far as how to teach this EL population they knew little about.

Starting kindergarten at the age of five without having attended pre-school, I struggled to learn English as a child. At home, I conversed mostly in Hmong and attempted English as often as possible. Most of my friends at the time were other EL students; thus, we did not have any proper English speaking role models. With the challenges of learning English, I was held back in kindergarten. My teacher thought I had a speech impediment due to my poor English skills. This struggle is common for most ELs. Too often, I hear teachers make negative comments that ELs are just not motivated or trying hard enough. Little do these teachers understand the challenges of learning English. As an educator today, I still see this problem as an issue. Although teachers are required to have a Crosscultural, Language \& Academic Development (CLAD) credential, they may still lack the necessary skills to effectively teach EL students. Moreover, some teachers may not be as passionate about teaching ELs. They may even see ELs as a burden and complain about having to teach these students.

When my parents arrived in America, they were struggling to survive in a country where the language and culture were very different from their own. My parents felt that it was important for us to keep our identity. We continued practicing our traditional customs while adapting to the American culture. At times, I did experience a "culture clash." In the Asian culture, for example, it is rude to look someone in the eyes when they are speaking to you; instead, one needs to look down as a sign of respect. I can still remember some teachers getting upset due to this cultural misunderstanding. I was really being respectful, but they misunderstood my looking down as being the opposite. I quickly learned to look at people when they spoke. Griswold (2004) stated that cultural ignorance or misunderstanding can lead to highly undesirable outcomes. Fortunately, I was never punished for looking down. However, I was 
confused as a child. Do I look up or do I look down? As educators, we need to be culturally competent and have a basic understanding of different cultures without overgeneralizing them.

When it comes to education, my parents have always been very supportive. They value education and believe it is the key to success in America. Like most parents, they want the best for their children. Although my parents could not help with my schoolwork, they supported and encouraged me in other ways. For instance, my parents always made sure I had food in my stomach. My mom would prepare home-cooked meals every day and I always had clean clothes to wear for school. My parents attended parent conferences when asked to by teachers, but they did not participate in other school events or activities. The academic side of school was more important to them. They respected and supported any teacher decisions. In some cultures such as mine, it is considered disrespectful to question the authority of teachers. As an educator, I notice these same values in most parents of EL students. Unfortunately, some teachers misunderstand the lack of parent participation as a sign of laziness or unwillingness. We are quick to judge and misinterpret what we see. Thus, we need to understand these cultural differences.

Growing up, I always liked school. I was a well-behaved student who managed to stay out of trouble. I also liked most of my teachers, but I always felt disconnected from many of them. They did not seem to take a genuine interest in my education. I felt they did not have any confidence in my academic abilities nor did they have any high expectations of me. According to Paccione (2000), there is ample research to suggest that teachers have significantly different expectations of students based on race, class, and gender. This influences teachers' assumptions regarding how students will perform academically in a school setting. Generally, minority students are perceived by teachers as lower performing. Unfortunately, teachers are rarely aware that they have lower expectations of students of color. Paccione's (2000) findings would be true in my experience as a student. As an educator today, I still see this difference in expectations for EL students in some teachers. Just recently, a teacher said to me that students who do not speak English or are limited in English skills should not be allowed to attend school since they lower test scores. These negative comments upset me, especially when they are made by educators who are supposed to help these students succeed. Sometimes, we as educators are so wrapped up in testing and increasing our test scores that we forget that our students are human beings, and they need teachers who care about them. Most importantly, they need teachers who believe in them.

Payne (1996) stresses that the role of the educator is "not to save the individual, but rather to offer a support system, role models, and opportunities to learn, which will increase the likelihood of the person's success" (p. 113). Additionally, Suarez-Orozco et al. (2009) found that school-based supportive relationships proved to be the most robust of the individual contributing factors bridging the gap between home and school cultures and providing important feelings of opportunities for success in the school setting. That kind of relationship existed only when I met my sixth grade teacher, Miss Sasaki. Prior to her, I did not have the kind of teacher-student relationship that would influence me in a positive way and have such a profound effect in my education and life. Miss Sasaki seemed to genuinely care about me as a student and as a person. She understood that her caring for students made an immense difference in how we experienced schooling. All teachers should have a general understanding of Nel Noddings (1992) "ethic of care" theory. Noddings believes that whether and how teachers and schools care for their students makes an immense difference in how students experience schooling.

Although most of her students were ELs from diverse backgrounds, Miss Sasaki refused to see "deficits" in anyone of us. Instead, she embraced our differences and saw our potential. She encouraged me to challenge myself and step out of my comfort zone. While most teachers 
neglected multicultural education, Miss Sasaki embraced it. Every day, she read a multicultural book to the class and taught us something about her Japanese heritage. The multicultural books she read depicted other cultures in a positive light. She encouraged us to embrace our own heritage and be proud of who we were. It was then that I really began to appreciate and take pride in my own culture. Prior, I felt I had to assimilate to the American culture and deny my own culture to "fit" in. I felt I had to choose between the two cultures. Even though my parents taught me to never forget my heritage and who I am, it was difficult at times identifying with who I was and who I should be. When I noticed how Miss Sasaki embraced her Japanese heritage and how proud she was to be Japanese American, I understood that it was okay for me to be Hmong American and to embrace my culture.

I may be from another country and speak another language, but these differences were no longer deficits. In fact, I realized it would be to my benefit to learn how to read and write in my primary language. So, I took advantage of Sunday school at church and started learning how to read and write in Hmong. The interesting thing was that as I was learning to read and write in Hmong, I was also improving my English skills. At school, I noticed that if I could transfer an English word to a word in Hmong and make some kind of connection to what I already knew, it made more sense for me. As an English learner, I believe that speaking another language does not impede the learning of a second language. If anything, I believe it helps students learn a second language. As an educator, I always encourage students to maintain their native tongue and embrace their heritage.

In school, I remember celebrating holidays such as Easter, Thanksgiving, and Christmas. I can still recall my first Easter experience in kindergarten. Without understanding the tradition of dying eggs, my cousin peeled his eggs. We laughed as we wondered about this strange American tradition. During my school year, I was exposed to such experiences of American culture without much exposure to other multicultural activities. At school, I learned to assimilate and be American. I have to admit it was exciting learning the customs of a new culture. At the same time, I wished that schools would have validated my culture and my experiences since they were just as important to me.

Drawing on my own positive experiences in sixth grade, I try to provide similar experiences for EL students so they can be proud of their heritage. For example, as a former teacher, when my Spanish speaking EL students left for Mexico for a month, I encouraged them to take those opportunities to get to know their families and learn about their own culture. I understood that leaving to visit family was part of their traditions and was important to them. When students did their heritage reports, I expected them to share what they learned about their culture. These heritage reports further provided me with additional knowledge pertaining to my students; thus, strengthening the student-teacher relationships I had with my students. More importantly, I was able to build on my students' experiences and validate them. Over the years, I have learned so much from my own schooling experiences and from my students. I can only hope that I have inspired and encouraged them the way Miss Sasaki inspired me.

\section{About the Author}

Kay Vang is the assistant principal at Apricot Valley Elementary School in Patterson California. She has taught nine years in the classroom and two years as the English Learner Instructional Coach. She has a BCLAD (Hmong) and is currently a doctoral student at California State University Stanislaus. 


\section{References}

Abedi, J., \& Gandara, P. (2006). Performance of English language learners as a subgroup in large scale assessment: Interaction of research and policy. Educational Measurement: Issues and Practice, 19, 36-46.

Arroyo, E. (2007). A+RISE. Retrieved October 2, 2009, from http://www.arisek12.com/

Cummins, J. (1999). BICS and CALP: Clarifying the distinction. (ERIC Document Reproduction Service No. ED438551)

Gandara, P., Rumberger, R., Maxwell-Jolly, J. \& Callahan, R. (2003). English learners in California schools: Unequal resources, unequal outcomes. Educational Policy Analysis Archives, 11, 1-54.

Griswold, W. (2004). Cultures and societies in a changing world._Thousand Oaks, CA: Pine Forge Press.

Howard, E., \& Christian, D. (2002). Two-way immersion 101: Designing and implementing a two-way immersion education program at the elementary level. Santa Cruz, CA and Washington DC: The Center of Research on Education, Diversity \& Excellence.

Nieto, S. (2005). Public education in the twentieth century and beyond: High hopes, broken promises, and an uncertain future. Harvard Educational Review, 75, 43-64.

Noddings, N. (1992). The challenge to care in schools: An alternative approach to education. New York: Teachers College Press.

Olsen, L. (2009). The role of advocacy in shaping immigrant education: A California case study. Retrieved April 2, 2009, from Teacher College Record Web site: www.tcrecord.org

Paccione, A. V. (2000). Commitment to Multicultural Education. Retrieved March 15, 2009, from Teacher College Record Web site: www.tcrecord.org

Payne, R.K. (1996). A framework for understanding poverty. Highlands, TX: aha! Process, Inc.

Sadovnik, A. R. (2001). Basil Bernstein. Retrieved May 1, 2009, from California State University of Stanislaus Web site: http://www.ibe.unesco.org/fileadmin/user_upload/ archive/publications/ThinkersPdf/bernsteine.pdf

Stein, S. (2004). The culture of education policy. New York: Teachers College Press.

Stevens, E., Wood, G., \& Sheehan, J. (2004). Justice, ideology and education: An introduction to the social foundations of education ( $4^{\text {th }}$ ed.). Boston: McGraw-Hill.

Suarez-Orozco, C., Pimentel, A., \& Martin, M. (2009). The significance of relationships: Academic engagement and achievement among newcomer immigrant youth. Retrieved April 21, 2009, from Teacher College Record Web site: www.tcrecord.org

Teaching Diverse Learners. (2006). The Education Alliance at Brown University. Retrieved April 13,2009, from http://www.alliance.brown.edu/tdl/

Walqui, A. (2006). Scaffolding instruction for English language learners: A conceptual framework. The International Journal of Bilingual Education and Bilingualism, 9, 159180. 


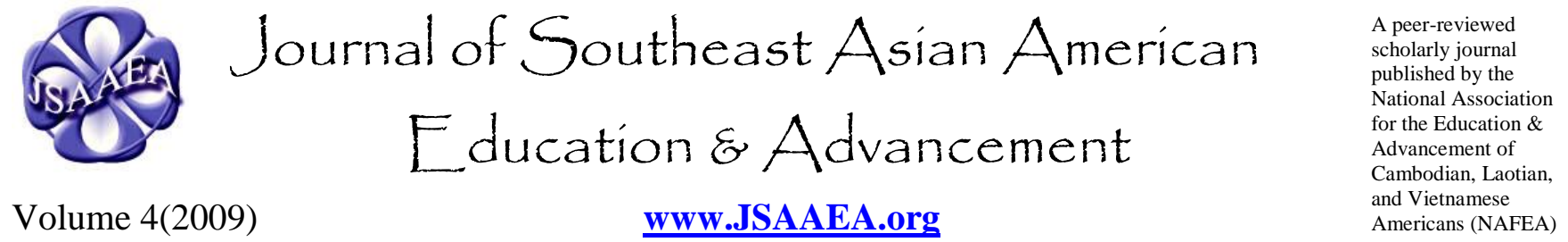

\author{
Editor \\ Dr. Wayne E. Wright \\ University of Texas, San Antonio \\ Associate Editors \\ Dr. Chhany Sak-Humphry \\ University of Hawaii \\ Dr. KimOanh Nguyen-Lam \\ California State University, Long Beach \\ Book Review Editor \\ Vichet Chhuon \\ University of California-Santa Barbara \\ Creative Works Editor \\ Phouang Hamilton \\ Washington Office of Superintendent of Public Instruction \\ Special Advisor \\ Anne Frank \\ University of California, Irvine, Southeast Asian Archives \\ Editorial Assistant \\ Mariana Kuhl \\ University of Texas, San Antonio
}

Comments and questions for the editorial staff may be directed to jsaaea@ lists.sis.utsa.edu

\title{
Editorial Review Board
}

\author{
Dr. Carl L. Bankston III \\ Tulane University \\ Dr. Phala Chea \\ Lowell Public Schools \\ Dr. Changming Duan \\ University of Missouri, Kansas City \\ Dr. Nancy H. Hornberger \\ University of Pennsylvania \\ Dr. Peter Nien-Chu Kiang \\ University of Massachusetts, Boston \\ Dr. Stacey Lee \\ University of Wisconsin, Madison
}

\author{
Dr. Pollie Bith-Melander \\ Asian and Pacific Islander Wellness Center \\ Dr. George Chigas \\ University of Massachusetts, Lowell \\ Dr. Sophal Ear \\ U.S. Naval Postgraduate School \\ Dr. Samlong Inthaly \\ Minneapolis Public Schools \\ Dr. Kevin K. Kumashiro \\ University of Illinois, Chicago \\ Dr. David Chanpannha Ley \\ Montgomery County Public Schools
}


Dr. Sue Needham

California State University, Dominguez Hills

Dr. Max Niedzwiecki

Daylight Consulting Group

Dr. Clara Park

California State University, Northridge

Dr. Loan T. Phan

University of New Hampshire

Dr. Karen Quintiliani

California State University, Long Beach

Dr. Fay Shin

California State University, Long Beach

Dr. Yer J. Thao

Portland State University

Dr. Khatharya Um

University of California, Berkeley

Dr. Terrence G. Wiley

Arizona State University
Dr. Bic Ngo

University of Wisconsin-Madison

Dr. Leakhena Nou

California State University, Long Beach

Dr. Mark Pfeifer

Texas A\&M University, Corpus Christi

Dr. Bounlieng Phommasouvanh

Minnesota Department of Education

Dr. Kalyani Rai

University of Wisconsin, Milwaukee

Dr. Nancy J. Smith-Hefner

Boston University

Dr. Myluong Tran

San Diego State University

Dr. Linda Trinh Vo

University of California, Irvine

Dr. Zha Blong Xiong

University of Minnesota

Dr. Kou Yang

California State University, Stanislaus

\section{Doctoral Student Editorial Review Board}

Keo Chea
University of Pennsylvania
Loan Dao
University of California, Berkeley
Ha Lam
Arizona State University
Vanna Som
Harvard University
Giang Pham
University of Minnesota
Tinou Tran
University of Houston, Texas
Phitsamay Sychitkokhong Uy
Harvard University

Keo Chea

Loan Dao

Ha Lam

Vanna Som

Giang Pham

Giang Pham

Tinou Tran

Phitsamay Sychitkokhong Uy

Harvard University
Peter Tan Keo

Vichet Chhuon

University of California, Santa Barbara

Annie BichLoan Duong

San Joaquin County Office of Education

Ravy Lao

University of California, Santa Barbara

Rassamichanh Souryasack

University of California, Santa Barbara

Layheng Ting

State University of New York, Albany

Loan Tran

University of California, Santa Barbara

Yang Sao Xiong

University of California, Los Angeles

Columbia University 